\title{
Peningkatan Kinerja Guru SMA Negeri di Kota Kediri dalam Perspektif Ujian Nasional
}

\author{
Suwarno $^{1}$, Sugeng Widodo ${ }^{2}$, Teguh Pramono $^{3} \&$ Rizki Yudha Bramantyo ${ }^{4}$ \\ Prodi Ilmu Administrasi Publik FISIP \\ Universitas Kadiri \\ Corresponding author: ${ }^{1}$ suwarno@unik-kediri.ac.id \\ ²sugengwidodo@unik-kediri.ac.id \& ${ }^{3}$ tghpram@unik-kediri.ac.id
}

Fakultas Hukum Universitas Kadiri

${ }^{4}$ rizki bramantyo@,unik-kediri.ac.id

\begin{abstract}
The purposes of this study are to see teacher performance measured by the conduct of national leaving exam in Kediri city. The study used qualitative approach to which content analysis was done. For the indepth analysis, observation and interview were completed. After the data were collected, a trustworthiness of data was done by comparing various data. Data were analyzed using interactive model proposed by Miles and Huberman (1984). Results show that to perform the national leaving exam, principals assigned teachers to well perform since the preparation of curriculum, teaching materials, teaching methods and assessment tryout, to which the following well-prepared instructional designs were developed: enrichment of teaching materials, addition of teaching hours, learning guidance, tryout of national leaving exam, as well as guidance to mental and spiritual.
\end{abstract}

Keywords: national leaving exam, performance, enrichment, teaching materials.

\section{PENDAHULUAN}

Dalam rangka menghadapi era globalisasi secara total yang melanda seluruh negara dan bangsa di dunia. Khususnya negara Indonesia menghadapi dua (2) tantangan besar, yaitu desentralisasi (secara internal) dan globalisasi secara eksternal, yang berupa persaingan antara lembaga dalam satu pemerintahan serta persaingan antar bangsa dan negara sebagai bentuk persaingan global. Oleh karena itu setiap sumberdaya manusia harus ditingkatkan guna memajukan bangsa dan negara. dan juga bisa berkompetisi dalam suatu pemerintahan. Upaya peningkatan kualitas sumberdaya manusia menjadi tanggung jawab negara. Hal ini sebagaimana yang terdapat pada pembukaan Undang-undang Dasar 45 bahwa “.........memajukan 
kesejahteraan, mencerdaskan kehidupan bangsa, dan ikut melaksanakan ketertiban dunia". Lebih lanjut negara melalui UUD 45 pasal 31 terdapat tiga point penting tentang pendidikan setiap warga negara, yaitu "setiap warga negara berhak mendapat pendidikan, setiap warga negara wajib mengikuti pendidikan dasar dan pemerintah wajib membiayainya".

Pendidikan sebagai media untuk menguasai dunia, pembangunan pendidikan menjadi strategi dalam memajukjan bangsa. Oleh karenanya pembangunan di bidang pendidikan harus terus menerus dilakukan dan ditingkatkan secara komprehensip, sehingga pada gilirannya dapat menghasilkan sumber daya manusia Indonesia yang cerdas, trampil dan berakhlak mulia serta mampu bersaing baik dalam skala nasional maupun global.

Mendasarkan pada pernyataan di atas, jelas bahwa pemerintah bertanggung jawab penuh atas kualitas sumberdaya setiap warga negara. Disadari atau tidak dan mau ataupun tidak mau sumberdaya manusia harus terus dipacu dan dikembangkan dalam rangka memajukan bangsa. Salah satu bentuk atau cara meningkatkan sumberdaya manusia adalah dengan memajukan bidang pendidikan, baik itu pendidikan formal maupun non formal. Salah satu upaya untuk mengetahui keamjuan aspek pendidikan dengan melakukan monitoring dan evaluasi. Kegiatan tersebut harus dilakukan secara berkala terstruktur, terkoordinir dan terprogram. Hal tersebut sudah tampak pada kurikulum 13 yang kemudian dijabarkan dalam kegiatan guru dalam melaksanakan pembelajaran, antara lain guru harus menyusun perencanaan pembelajaran yang didalamnya termuat rencana evaluasi, baik itu harian maupun akhir semester. Semua itu dilakukan dan merupakan kewajiban dari guru, hanya semata-mata untuk mencapai kualitas lulusan yang maksimal.

Alat evaluasi yang digunakan untuk mengukur kualitas lulusan di SMA sampai saat ini adalah Ujian Nasional (UN), yang diadakan pada akhir semester siswa kelas XII setiap tahun. Hal tersebut merupakan kebijakan pemerintah dalam bidang pendidikan sebagai bentuk pengendalian mutu pendidikan secara nasional. Disamping juga sebagai bentuk akuntabilitas penyelenggara pendidikan kepada pihak-pihak yang berkepentingan.

\subsection{Rumusan Masalah} Nasiponal

Bagaimana kinerja guru SMA Negeri di Kota Kediri dalam Perspektif Ujian

\subsection{Tujuan Penelitian}

Ingin mendeskripsikan kinerja Guru SMA Negeri di Kota Kediri dalam Perspektif Ujian Nasional 


\section{TINJAUAN PUSTAKA}

Dalam rangka mencapai standar kelulusan di setiap mata pelajaran sebagaimana telah di atur dalam Ujian Nasional, maka banyak cara atau upaya yang dilakukan sekolah, antara lain program pengayaan atau remedial. Program tersebut bertujuan untuk lebih mempersiapkan siswa dalam menghadapi ujian nasional. Persiapan dimaksud tidak hanya siswa namun juga guru, pimpinan sekolah maupun seluruh peranglkat sekolah. Walaupun demikian fokus kegiatan tetap tertuju pada siswa (Nurhayati, 2010: 2), sebagai objek yang menghadapi ujian nasional Sementara itu Prayitno dalam Ema Sumawati (2008), mengartikan pengayaan atau remedial tersebut dengan bimbingan belajar agar siswa mampu membentuk kebisaaan belajar yang baik, mengembangkan rasa ingin tahu, dan menumbuhkan motivasi untuk mengembangkan ilmu pengetahuan.

Bimbingan belajar tersebut diberikan oleh seorang guru atau orang yang memiliki keahlian dibidangnya dalam rangka melakukan pemahaman dirinya untuk beradaptasi dengan tuntutan lingkungan agar dapat mencapai hasil yang maksimal. pemahaman tentang diri sendiri dengan lingkungan, memilih, menentukan, dan menyusun rencana sesuai dengan konsep dirinya, dan tuntutan lingkungan sesuai dengan norma/kaidah yang berlaku (Anas Salahudin (2010).

Proses bimbingan dapat diartikan sebagai proses mental yang akan mengarah pada proses persepsi terhadap sesuatu. Jika sesuatu yang data pada kita itu menurut persepsi kita baik maka kita akan melakukan, tetapi jika persepsi kita tidak baik maka kita tidak melakukan. Proses bimbingan mengarah pada sikap dan tingkah laku, karena menyangkut pemikiran kita untuk dapat beradaptasi dengan hal yang baru, yaitu bimbingan belajar. Pengayaan materi, peningkatan prestasi akademik, program intensif dan try out tersebut sebagai program akademik yang tidak ada dalam kurikulum, sehingga hal tersebut menuntut siswa untuk bisa beradaptasi dengan kegiatan tersebut. Oleh karena itu diperlukan arahan, sosialisasi agar dapat melakukan pemahaman yang sama akan tujuan dari kegiatan tersebut.

Mental yang sehat tercermin dari kehidupannya yang terencana, memiliki skala priorityas dalam bertindak, mana yang lebih penting itu yang diprioritaskan, memiliki tujuan hidup yang jelas, bisa menjaga kesehatan fisiknya termasuk pola makan, pola istirahat, memiliki pola interaksi sosial yang baik dengan siapa saja di manapun berada.

\section{METODE}

Kajian tentang peningkatan kinerja guru SMA Negeri kota Kediri dalam perspektif Ujian Nasional melalui tahapan:

1) Melakukan telaahan literatur, hasil kajian sebelumnya, laporan dinas, jurnal, dan sejenisnya untuk memahami dan mengkaji kondisi existing Ujian Nasional dan Pembelajaran Guru. 
2) Melakukan kajian terhadap berbagai fenomena yang ada dalam pelaksanaan Ujian Nasional,

3) Melakukan pengumpulan data melalui wawancara dengan kepala sekolah, wakil kepala sekolah bidang kurikukum (pembelajaran), wali kelas, guru bidang studi untuk mata pelajaran yang di Ujikan Nasional,

4) Melakukan sebagaimana sekolah lain yang dianggap memiliki kualitas penyelenggaraan pendidikan yang baik, khususnya dalam menyelenggarakan Ujian Nasional.

5) Melakukan uji keabsahan data yang kemudian dilanjutkan dengan menganalisis berbagai data yang terkumpul melalui analisis interaktif dari Miles dan Huberman sebagai langkah untuk mencapai hasil penelitian dan rekomendasi. Teknik penentuan informan dengan teknik purposive, dengan pertimbangan yang bersangkutan diprediksi yang paling menguasai materi penelitian.

\section{HASIL}

\subsection{Pengayaan Materi Pelajaran}

Salah satu upaya sekolah di kota Kediri untuk mempersiapkan siswa dalam menghadapi Ujian Nasional dengan melakukan pengayaan materi. Kegiatan tersebut dilaksanakan secara organis melalui perencanaan, pelaksanaan kemudian juga evaluasi. Hal ini pebting guna untuk mengetahui kelemahan-kelemahan dari kegiatan tersebut guna perbaikan ke depan. Selain itu juga perlu adanya dukungan pihak sekolah. Deskripsi tersebut sebagaimana dijelaskan oleh wakil kepala sekolah bidang kurikulum bahwa berbagai upaya akademik dilakukan sekolah guna mempertahankan dan terus meningtkatkan kualitas kelulusan Ujian Nasional, disamping pelaksanaan pembelajaran sebagaimana yang telah dilakukan juga sekolah melaksanakan program pengayaan materi dengan penekanan pada materi/bagian pelajaran yang dirasakan sulit bagi siswa, memberikan Tugas-tugas/Pekerjaan Rumah dan membahas soal-soal, diskusi dan dikerjakan secara bersama-sama di sekolah"

\subsection{Peningkatan Prestasi Akademik}

Peningkatan prestasi akademik tersebut diwujudkan dengan melakukan tambahan jam pelajaran di luar jam belajar reguler yaitu dengan menambah 1 jam pelajaran sebelum dimulai jam pelajaran reguler (khusus bagi siswa kelas XII). Kegiatan tersebut dilaksanakan pada hari Selasa, Rabu dan Sabtu. Penambahan jam pelajaran tersebut hanya khusus bagi pelajaran yang diujikan nasional. Materi yang diberikan antara lain pembahasan soal-soal sesuai kisi-kisi UN (SKL), terutama soalsoal ujian tahun sebelumnya yang sulit dijawab oleh siswa, serta pemanfaatan perpustakaan on line" (Hasil wawancara dengan Kepala Sekolah dan Wakil Bidang Kurikulum, 2019).

\subsection{Program Intensif}


Seorang wali murid kelas XII dan guru pengajar kelas XII menjelaskan, bahwa untuk mempersiapkan siswa menempuh Ujian Nasional dan sebagai upaya meningkatkan kualitas lulusan maka yang ditempuh sekolah dengan mengadakan "program intensif". Program intensif tersebut diadakan setelah ujian sekolah dan ujian praktek selesai. Program ini dikenal juga program dua minggu, sebab program ini dilaksanakan selama dua minggu secara intensif yaitu setiap hari sebelum jam pelajaran reguler dimulai yaitu jam 6.00 sampai jam 6.45. Adapun materi yang menjadi pembahasan adalah mata pelajaran yang diujikan nasional saja, bentuknya masih sama dengan program lain yaitu pembahasan soal-soal, latihan soal dan lainlain yang dianggap dapat mendukung dan meningkatkan kualitas lulusan. .

\subsection{Try Out}

Try out merupakan kegiatan evaluasi pembelajaran yang dilaksanakan oleh sekolah. Dalam pelaksanaan try out, sekolah bekerja sama dengan suatu lembaga untuk melakukan semacam latihan ujian, sehingga jika hasil try out ini baik kemungkinan besar ujian nasional juga baik. Try out tersebut merupakan program Dinas Pendidikan Cabang Kota Kediri yang dilaksanakan oleh sekolah (khususnya SMA Negeri di Kota Kediri). Program try out tersebut dilaksanakan tiga kali dalam dua semester. Pelaksanaan try out pada semester V dilaksanakan sebelum pelaksanaan Ujian Sekolah. Adapun pelaksanaan try out pada semester 6 sebelum Ujian Sekolah dan setelah Ujian Nasional.

\subsection{Pembinaan Mental Spiritual}

Pembinaan mental spiritual juga dilakukan oleh sekolah dengan tujuan untuk menanam mental spiritual kepada siswa, sehingga siswa memiliki bekal mental yang stabil. Hal ini penting agar siswa memiliki stabilitas mental dan tidak mudah gugup, grogi dan labil. Pembinaan mental tersebut antara lain pemberian pengajian (santapan rohani), secara berkala bisa juga dalam bentuk istighosah atau pembacaan-pembacaan doa. Kegiatan tersebut dilakukan sejak siswa masuk di kelas 3. Kegiatan lain yaitu dengan mengadakan doa bersama (Istighosah), dan berdoa bagi agama lain.

\section{PEMBAHASAN}

Sampai saat ini Ujian Nasional yang dilaksanakan oleh pemerintah pusat masih menjadi target program bagi para penyelenggara pendidikan. Bahkan keberhasilan guru dalam melaksanakan pembelajaran, Kepala Sekolah dalam melaksanakan manajemen sekolah. Tidak hanya itu Ujian Nasional menjadi cerminan dari kinerja sekolah, sebab hampir seluruh aktifitas guru, khususnya guru kelas XII menjadi klimaks dari kegiatan edukatif, pembelajaran, sosial dan kepribadian. Oleh karena itu tidak sembarang guru yang ditugasi mengqjar di kelas XII. Namun guru yang sudah berpengalaman, profesional, dan aktif serta kreatif. 
Mendasarkan pada kurikulum sekolah, jam pelaksanaan pembelajaran sudah lebih dari cukup untuk menuntaskan pelaksanaan pembelajaran. Namun demikian hal tersebut dirasa masih belum cukup untuk dapat mencapai nilai kelulusan ujian nasional yang optimal. Oleh karena itu berbagai upaya dilakukan oleh sekolah untuk mempersiapkan siswa dalam mengahadapi ujian sekolah maupun ujian nasional. Salah satu upaya sekolah tersebut adalah dengan meningkatkan kinerja guru, baik itu dalam bidang perencanaan, pelaksanaan pembelajaran yang profesional lengkap dengan pemnggunaan berbagai ketrampilan guru ,maupun keahlian guru, monitoring dan evaluasi, serta daya dukung sekolah yaitu penggunaan perangkat sekolah dalam kaitannya dengan kinerja guru dalam pelaksaknaan pembelajaran, misalnya penggunaan perpustakaan manual maupun elektronik, WiFi sekolah gratis, Pengayaan materi pelajaran, peningkatan prestasi akademik, program intensif, try out, dan pembinaan mental spiritual yang dilakukan secara berkala dan berkelanjutan yang diakhiri dengan doa bersama (Istighosah).

Peningkatan kinerja guru dimaksud untuk mencapai tujuan sekolah dalam mengikuti ujian nasional. Oleh karena itu fokus dari kegiatan ini adalah peningikatan kemampuan siswa dalam memahami, menguasai matyeri pelajaran yang telah diberikan guru sesuai dengan tujuan dan tuntutan kurikulum yang berlaku. Bentuk kegiatan peningkatan kinerja guru tersebut antara lain pembahasan berbagai materi pelajaran melalui pembahasan berbagai bentuk soal sesuai dengan kisi-kisi, latihan soal, pemecahan soal, pendalaman materi pelajaran, diskusi bersama. Dalam hal ini siswa diberikan waktu, materi, maupun kesempatan seluas-luasnya untuk bertanya apa yang belum dipahami, meminta apa yang belum mereka dapat, meminta petunjuk tentang bagaimana menyelesaikan, memecahkan, membahas soal-soal ujian nasional, serta bagaimana sistem ujian nasional dengan sistem elektronik tersebut. Oleh karena itu try out sangat penting dilakukan dalam rangka membiasakan diri siswa dengan suasana ujian nantinya. Berbagai upaya yang dilakukan tersebut dalam rangka memberikan kepercayaan, keyakinan, rasa optimis bahwa dia (siswa) bisa mengerjakan ujian nasional dan lulus, ini sangat penting sebagai tambahan rasa percaya diri.

\section{SIMPULAN}

Peningkatan kinerja dimaksud adalah pengerahan segala ketrampilan dalam pelaksanaan pembelajaran, pelaksanaan profesionalisme sosial (membangun kedekatan interaksi siswa dan guru), serta pengerahan seluruh daya dukung sekolah dalam peningkatan pelaksanaan pembnelajaran di sekolah baik internal maupun eksternal). Upaya-upaya yang dilakukan oleh guru sebagai bentuk peningkatan kinerja guru dalam mempersiapkan siswa menghadapi UN antara lain: (1) Pengayaan materi pelajaran, (2) Peningkatan Prestasi Akademik, (3) Program Intensif, (4) Melaksanakan Try Out, dan (5) Melaksanakan Pembinaan Mental Spiritual. 


\section{DAFTAR PUSTAKA}

Anas Salahuddin. 2010. Bimbingan\&Konseling.CV. Bandung: Pustaka Setia.

Ema Sumawati. 2008. Pengembangan Model Bimbingan Kelompok dengan Teknik Role Playing untuk Mengembangkan Kepercayaan Diri Siswa. Prodi Bimbingan dan Konseling, Program Pascasarjana, Universitas Negeri Semarang, Indonesia

Kusnandar. 2007. Guru Profesional. Jakarta: PT Raja Grafindo

Kusnandar. 2003. Undang-Undang Republik Indonesia nomor 20 tahun 2003 tentang Sistem Pendidikan Nasional.

Nurhayati. 2010. Manajemen Operasi. Edisi Revisi, Andi . Yogyakarta.

Sudrajat. 2008. Kompetensi Guru dan Peran Kepala Sekolah. Diambil dari www.wordpress.com.

Suwarno. 2012. Perubahan Pola Pencaharian Nafkah Dalam Kaitannya dengan Persepsi Masyarakat Pedalaman Terhadap Pendidikan. Jurnal Economia Volume 8 Nomor. 2. Oktober 2012 
CENDEKIA, Vol. 14 No. 1 April 2020

p ISSN: 1978 2098; e ISSN: 2407 8557

Https://soloclcs.org; Email: cendekiaoslo@gmail.com Center of Language and Cultural Studies, Surakarta, Indonesia

Suwarno; Widodo, Sugeng; Pramono, Teguh \& Bramantyo, Yudha, Rizki. (2020). Peningkatan Kinerja Guru SMA Negeri di Kota Kediri dalam Perspektif Ujian Nasional. Cendekia (2020), 14(1): 43 50. DOI: 10.30957/cendekia.v14i1.609. 